\title{
EDUCATION AND SOCIAL TRUST CASE STUDY: ANTI-VACCINATION PRACTICES IN RUSSIA
}

\author{
EDUCAÇÃO E CONFIANÇA SOCIAL ESTUDO DE CASO: PRÁTICAS \\ ANTIVACINAÇÃO NA RÚSSIA
}

\author{
EDUCACIÓN Y CONFIANZA SOCIAL ESTUDIO DE CASO: PRÁCTICAS \\ ANTIVACUNAS EN RUSIA
}

\author{
Aida Nailevna NURUTDINOVA ${ }^{1}$ \\ Alina Aleksandrovna LUSHAVINA ${ }^{2}$ \\ Vera Nikolaevna ARGUNOVA ${ }^{3}$
}

\begin{abstract}
Modern trust studies have begun to believe that education has a universally positive impact on trust. Education is often one of the most potent predictors of trust, more influential than age, income, wealth, health, or any other individual characteristic. Therefore, there are specific causes to consider that education sometimes enhances the propensity to trust. The article deals with the current issue of distrust of vaccination as an institutional practice of prevention and protection from diseases. The results of a sociological study conducted in 2016 and 2020 revealed that the refusal to vaccinate children is based on the education and life experience of parents themselves or other people who have faced post-vaccination complications. Participants in the study spoke about the voluntary nature of vaccination, including against coronavirus. The results indicated that that there is a positive correlation between education and trust in the society.
\end{abstract}

KEYWORDS: Society. Anti-vaccination practices. Education. Social trust.

RESUMO: Os estudos modernos sobre confiança começaram a acreditar que a educação tem um impacto universalmente positivo sobre a confiança. A educação costuma ser um dos indicadores mais potentes de confiança, mais influente do que a idade, renda, riqueza, saúde ou qualquer outra característica individual. Portanto, há causas especificas para considerar que a educação às vezes aumenta a propensão para a confiança. O artigo trata da questão atual da desconfiança na vacinação como prática institucional de prevenção e proteção contra doenças. Os resultados de um estudo sociológico realizado em 2016 e 2020 revelaram que a recusa em vacinar crianças é baseada na educação e na experiência de vida dos próprios pais ou de outras pessoas que enfrentaram complicações pós-vacinais. Os participantes do estudo falaram sobre a natureza voluntária da vacinação, inclusive contra o coronavírus. Os

${ }^{1}$ Kazan Federal University, Kazan - Russia. Candidate of sociological Sciences, associate Professor of the Department of General and ethnic sociology, Institute of social and philosophical Sciences and mass communications. ORCID: https://orcid.org/0000-0001-7453-3502. E-mail: aida.nurutdinova@kpfu.ru

${ }^{2}$ Independent research Center, Samara - Russia. Doctor-neurologist, sociologist. ORCID: https://orcid.org/00000003-3547-8592. E-mail: alina chemodanov@mail.ru

${ }^{3}$ Vyatka state University, Kirov - Russia. Doctor of social Sciences, Professor, faculty of history, political science and cultural studies, Institute of Humanities and social Sciences. ORCID: https://orcid.org/0000-0003-0643-8065. E-mail: v_argunova@mail.ru 
resultados indicaram que existe uma correlação positiva entre educação e confiança na sociedade.

PALAVRAS-CHAVE: Sociedade. Práticas antivacinação. Educação. Confiança social.

RESUMEN: Los estudios modernos sobre la confianza han comenzado a creer que la educación tiene un impacto universalmente positivo en la confianza. La educación es a menudo uno de los predictores más potentes de la confianza, más influyente que la edad, los ingresos, la riqueza, la salud o cualquier otra característica individual. Por tanto, existen causas concretas para considerar que la educación en ocasiones potencia la propensión a la confianza. El artículo aborda el tema actual de la desconfianza hacia la vacunación como práctica institucional de prevención y protección de enfermedades. Los resultados de un estudio sociológico realizado en 2016 y 2020 revelaron que la negativa a vacunar a los niños se basa en la educación y la experiencia de vida de los propios padres u otras personas que se han enfrentado a complicaciones posvacunales. Los participantes del estudio hablaron sobre la naturaleza voluntaria de la vacunación, incluso contra el coronavirus. Los resultados indicaron que existe una correlación positiva entre educación y confianza en la sociedad.

PALABRAS CLAVE: Sociedad. Prácticas antivacunas. Educación. Confianza social.

\section{Introduction}

Various aspects of vaccination have now become more relevant in connection with the coronavirus pandemic and the promotion of the idea of vaccination as a preventive measure. There is a growing movement of anti-vaccinators around the world, whose participants are opposed to the use of vaccines as a means of preventing epidemic diseases. In this regard, it is important to consider the practices and reasons for refusing vaccination in terms of trust in doctors and the health care institution. Vaccination is a medical intervention performed by doctors who are not only legally but also morally responsible for the health and life of patients. There is no consensus among medical practitioners, epidemiologists, and biologists about the impact of vaccines on human health. Moreover, it was doctors and scientists who initiated the anti-vaccination movement in the world. In Great Britain, the "First national anti-Vaccination League" was established in 1866. In the United States in 1879, the "American society against vaccination" appeared. Currently, there is a "European Forum for Vaccine vigilance" (EFVV). In Russia, the anti-vaccination movement at the end of the XX century began virologist $\mathrm{G}$. P. Chervonskaya, homeopath A. Kotok, surgeon F. G. Uglov (UGLOV, [n.d.]).

The main proponent of vaccination is the World health organization. Its experts say that the only factors affecting public health are vaccination and clean drinking water, and the percentage of vaccination among the population is a factor in economic growth. In their view, 
vaccination is a strategic investment in health care. This position is shared by official representatives of health systems in all countries of the world.

The massive increase in the practice of refusing vaccinations is a symptom of patients' distrust of this type of medical intervention. This puts a negative impact on the relationship between the doctor and the patient, weakens the authority of medicine. The specifics of communication between the doctor and the patient presuppose mutual trust, which is the most important condition for successful treatment. Sociology considers trust as a type of social connection, the opposite of formal relationships regulated by legal norms. Shtompka believes that such a social connection is a moral connection (VASIL'EVA, 1999). N. Luman characterizes trust as an emotional connection between people, a moral and psychological attitude, a generalized expectation of justice in actions from the interaction participant, and the fulfillment of their obligations (POROHOVSKAJA, 2018). Adam B. Seligman observes that trust is the Foundation of public relations.

Trust as a social bond implies that people have binding obligations towards others. The main components of this relationship are: the expectation of a decent attitude towards us; fulfillment of obligations; concern for the interests of others, the willingness to take action in their favor, even when our interests suffer. These three vectors create a moral space of trust in which social interaction takes place, including between the doctor and the patient.

This article analyzes the practices and reasons for refusing vaccinations of parents of young children, the opinions of practitioners and other specialists who speak out against vaccination. The goal is to find out how the refusal of vaccination affects the credibility of medical activities.

\section{Methods}

To study the problem, a sociological study was carried out. At the first stage, in 2016, 23 free interviews were conducted with parents aged 20 to 49 years from different cities of Russia and monitoring the actions of participants of the Pravda about vaccinations group in the Vkontakte social network using netnography. According to Gould's typology, we chose the "observer as participant" position (POLUHINA, 2014).

The "Truth about vaccinations" community (classified by Garcia, Standlee, Bechkoff, Cui) refers to a community of online contacts (POLUHINA, 2014).

At the second stage of the study in 2020, the case study method was used. The object of the study was the international round table "Stop compulsory vaccination! Post-vaccination 
complications", which took place on July 26, 2020 live on the Youtube channel of the news Agency "a to be honest".

A secondary analysis of the results of the all-Russian sociological Internet survey on coronavirus vaccination was also carried out (Independent research Center, September 2020, $\mathrm{n}=3700)$.

\section{Results and Discussion}

According to the results of the first stage of the study, two forms of refusal of vaccination were identified: total and partial. In the first case (there was a majority of such informants), parents refused all vaccinations for their children. In the second case, parents give their children some vaccinations against diseases that can cause negative consequences.

Informants who chose the total form of refusal can be divided into several groups. (1) Parents who have refused vaccinations since a certain period. This group included those who began to refuse after complications and adverse reactions because of vaccination, and those who were guided by information from the Internet and anti-vaccination literature (MAWSON et al., 2017). (2) Parents who refuse to vaccinate children immediately after the birth. In this group, it is worth noting parents who have experience of the negative consequences of vaccination of older children, which prompted them not to vaccinate younger children.

A stable anti-vaccination conviction is formed in parents under the influence of several factors. The main factor is a negative personal life experience or close acquaintances. In some cases, vaccine refusals are linked to informants' social connections. If there are vaccination refuseniks in the close circle of parents who are trusted by their parents, then their opinion becomes authoritative. Informants also take a negative attitude to vaccination from their parents, who also did not vaccinate their children (informants). In Russia today, there are families that have two or even three generations of unvaccinated children.

The results of the interview and analysis of the online resource revealed the following arguments against vaccinations. (1) Vaccinations are dangerous and harmful to the body, destroy the child's immune system, cause adverse reactions and long-term consequences that affect health (PETROVSKY, 2015). Therefore, there is not only a rejection of the need for vaccination, but also a loss of confidence in official methods of medicine and doctors (HOWSON et al., 1991).

The second argument (2) against vaccines is the belief that vaccinations are "biological weapons". This view is closely linked to distrust of the health system as a whole. Some parents 
interviewed suspected doctors of colluding with pharmaceutical companies that promote vaccines that informants believe are "biological weapons". Scandals in Mexico, the Philippines, and Africa were an important factor that convinced parents that vaccinations were "bioweapons". Then a hormone that causes infertility in women was found in the polio vaccine (TALWAR et al., 1994). The third argument (3) is based on the belief that vaccines are a profitable business for pharmaceutical companies, so they are lobbying for mandatory vaccination. The fourth argument (4). Vaccinations did not stop epidemics of dangerous diseases, and the presence of vaccination does not provide guarantees against the disease. The fifth argument (5). Vaccinated children get sick more often and more than unvaccinated children. This opinion is usually formed on the personal experience of parents when they monitor the health of their older (vaccinated) and younger (unvaccinated) children. Sixth argument (6). The Body itself must fight viruses and diseases. As a rule, this position is held by parents who practice non-drug forms of health improvement.

The desire to protect a child from vaccination is often regarded by parents as a "war" with the entire social system, as well as with relatives and acquaintances. They often become "enemies" for other parents, are criticized and condemned. At the same time, parents understand that society and the state put forward certain rules, including regarding vaccinations. Parents carefully prepare for refusal of vaccinations, study the laws, prescribed requirements, share their experience with others, and clearly build their arguments when communicating with medical professionals. The results of our research have shown that parents know their rights and obligations and are guided by the laws. Parents try to establish a dialogue with the government and health authorities. One of the options for parents is to create and distribute petitions against mandatory vaccinations and certain types of vaccination.

Distrust of vaccination breeds distrust of the health system, treatment methods, and some doctors. Parents who refuse to vaccinate their children often refuse to take medications, antibiotics, and turn more to traditional forms of treatment, homeopathy, and naturopathy. Parents pay great attention to a healthy lifestyle, disease prevention, and avoiding products containing genetically modified foods. Some of the community members are supporters of old Russian practices, engaged in health improvement and hardening of the body.

The second stage of the study (July 2020) included identifying the opinions of participants of the international round table "Stop compulsory vaccination! Post-vaccination complications". The analysis of parents' speeches confirmed the results obtained at the first stage concerning the reasons for refusing vaccination. Russian doctors talked about cases when the management of a medical institution forbade them to record post-vaccination consequences 
in the patient's personal card. Experts also separately noted the futility of mandatory vaccination against COVID-19, since the virus is constantly mutating, and the vaccine does not keep up with the new mutation. It was also suggested that it is impossible to make a high-quality vaccine in a few months, conduct the necessary tests, and identify all possible negative consequences. Human rights defenders who spoke at the round table raised the issue of legal protection against compulsory vaccination.

An important issue was raised about post-vaccination complications. First, it is very difficult to prove such consequences since the health system at all levels protects itself by refusing to recognize the link between the consequences and vaccination. Secondly, the amount of payments due to the negative consequences of vaccination is extremely small. They are not commensurate with the funds spent on treatment, physical and moral damage. Third, pharmaceutical companies benefit from post-vaccination complications: the number of users of insulin and other medications is growing (ANGELL, 2009).

The results of the all-Russian survey on coronavirus vaccination showed that most respondents (92.1\%) do not trust information about the extent of the spread of coronavirus, its dangers, methods of prevention and treatment coming from official sources to varying degrees. The vast majority of respondents do not want to be vaccinated (the sum of responses is more than $100 \%)$. Half of the respondents (50.4\%) are not ready to be vaccinated, because they do not trust all the vaccines that the World health organization has long been involved in, accused of sabotage of vaccines; $43.2 \%$ are not ready to be vaccinated, because the vaccine cannot be created before five years according to all scientific standards; $32.7 \%$ are not ready to be vaccinated, because there can be no reliable vaccine against coronavirus. Only $3.6 \%$ of respondents are ready to be vaccinated, of which: $2 \%$ will do it voluntarily, $0.9 \%$ - if there is an order about it throughout the country, $0.7 \%$ - if they are forced to work (Independent research Center, n./d.).

\section{Summary}

The practice of non-vaccination can be combined into several groups depending on family experience regarding vaccination. One group consists of families that have a negative experience of vaccinating older children. They categorically refuse to vaccinate younger children. In these families, distrust of doctors and the health care system is most pronounced. The other group consists of families in which there is a tradition of refusal of the vaccination. The parents themselves grew up without vaccinations and have a positive experience of life 
without vaccines. These families actively spread their positive example among other parents. The third group includes families who have strong beliefs against vaccines based on the analysis of other people's life experiences and literature. They do not vaccinate their children, but they may agree to some vaccinations under pressure from the education system. These parents are critical of medicine.

Among the reasons for refusing vaccination, concern for strengthening the child's immunity and fear of post-vaccination complications prevail (DÓREA, 2011). It should be noted that the practice of refusing vaccination is accompanied by alternative practices: a healthy lifestyle, including hardening and healthy nutrition; the use of traditional medicine; refusal of antibiotics, etc.

The results of the all-Russian Internet survey showed that the vast majority of Russians do not trust official information about the spread of the virus, do not consider it a serious disease and do not want to be vaccinated against covid-19.

\section{Conclusions}

The widespread practice of refusing vaccinations among parents, as our research has shown, is based on life experience. Negative health consequences, weakened immunity, disability, and sometimes the death of children, all this indicates the ambiguous impact of vaccinations on the human body. At the same time, the efforts of official medicine and the World health organization have created stereotypes of the positive impact of vaccines in society. In order to maintain trust in the relationship between the doctor and the patient, it is necessary, in our opinion, to have a flexible line of communication with parents who refuse to vaccinate their children. In addition, we need strict public control over the production of vaccines and their quality.

ACKNOWLEDGEMENTS: The work is performed according to the Russian Government Program of Competitive Growth of Kazan Federal University. 


\section{REFERENCES}

ANGELL, M. Drug companies \& doctors: a story of corruption. The New York Review, 15 Jan. 2009. Available: https://www.nybooks.com/articles/2009/01/15/drug-companiesdoctorsa-story-of-corruption/. Access: 10 Jan. 2021.

DÓREA, J. G. Integrating experimental (in vitro and in vivo) neurotoxicity studies of lowdose thimerosal relevant to vaccines. Neurochem Res., v. 36, n. 6, p. 927-938, 2011. Available: https://pubmed.ncbi.nlm.nih.gov/21350943/. Access: 10 Jan. 2021.

\section{HOWSON, C. P.; HOWE, C. J.; FINEBERG, H. V. Adverse Effects of Pertussis and} Rubella Vaccines: A Report of the Committee to Review the Adverse Consequences of Pertussis and Rubella Vaccines". Washington, DC: National Academies Press (US). 1991. pt. 5. Available: https://www.ncbi.nlm.nih.gov/books/NBK234368/. Access: 10 Jan. 2021.

INDEPENDENT RESEARCH CENTER. Results of an Internet survey on coronavirus vaccination. [n.d.]. Available: http://xn----7sbfhedbrfkjgf7af6bcairj9fsg.xn--p1ai/rezultatyinternet-oprosa-po-teme-vaktsinatsii-ot-koronavirusa/. Access: 10 Jan. 2021.

MAWSON1, A. R. et al. Preterm birth, vaccination and neurodevelopmental disorders: a cross-sectional study of 6- to 12-year-old vaccinated and unvaccinated children. Journal of Translational Science, v. 3, n. 3, p. 1-8, 2017. Available: https://www.oatext.com/pdf/JTS-3187.pdf. Access: 10 Jan. 2021.

PETROVSKY, N. Comparative safety of vaccine adjuvants: a summary of current evidence and future needs". Drug Saf., v. 38, n. 11, p. 1059-1074, 2015. Available:

https://www.ncbi.nlm.nih.gov/pmc/articles/PMC4615573/. Access: 10 Jan. 2021.

POLUHINA, E. Online surveillance as a method of data collection. Theoretical discourses and discussions. Inter, n. 7, p. 95-106, 2014.

POROHOVSKAJA, T.I. Trust as a moral phenomenon. Scientific notes of the V. I. Vernadsky Crimean Federal University. Philosophy. Political science. Culturology, v. 4, n. 70, p. 56-64, 2018.

TALWAR, G. P. et al. A vaccine that prevents pregnancy in women. Proc. Natl. Acad. Sci. USA, v. 91, p. 8532-8536, 1994. Available:

https://www.ncbi.nlm.nih.gov/pmc/articles/PMC44640/. Access: 10 Jan. 2021.

UGLOV, F. G. Review of V. A. Kopylov's article "About vaccinations". [n.d.]. Available: http://www.kopylov.ru/index.php/ct-menu-item-223/ct-menu-item-225/ct-menu-item-239/oprivivkakh. Access: 10 Jan. 2021.

VASIL'EVA, E. P. P. Sztompka. Hard-to-understand cultural factors in rapid social change. Trust, loyalty, solidarity. Social and human Sciences. Russian and foreign literature. Series 11. Sociology: an abstract journal, n. 2, p. 78-85, 1999. 


\section{How to reference this article}

NURUTDINOVA, A. N.; LUSHAVINA, A. A.; ARGUNOVA, V. N. Education and social trust case study: anti-vaccination practices in Russia. Revista on line de Política e Gestão Educacional, Araraquara, v. 25, n. esp. 6, p. 3516-3524, Dec. 2021. e-ISSN:1519-9029. DOI: https://doi.org/10.22633/rpge.v25iesp.6.16113

Submitted: 07/04/2021

Required revisions: 11/08/2021

Approved: 19/11/2021

Published: 30/12/2021

Processing and publication by the Editora Ibero-Americana de Educação. Correction, formatting, standardization and translation.

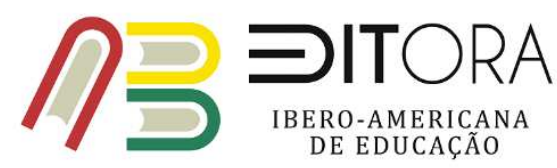

